\title{
Personnel
}

APPOINTMENTS

Richand ANABle has been appointed systems librarian, York University libraries.

Charles R. Andrews is now librarian of Freiberger Library, Case Western Reserve University.

Darlene Appelman has assumed the position of serials cataloger at Southern Illinois University library.

Jon R. Ashtow has been named assistant director for technical services at Temple University.

JEAN BARTON was appointed as a cataloger at Kansas State University library on July 1 , 1969.

Mrs. John Bartosh has joined the Marywood College library (Scranton, Pennsylvania) staff as assistant in charge of circulation.

RichARD A. BECK is assistant librarian for reference and supervisor of circulation at Kendall College, Evanston, Illinois.

RoBERT BELLANTI is the new serials librarian at the University of Nevada, Las Vegas.

J. Terry Bender has joined the staff of Hofstra University library as special collections librarian.

Rosella Berg has joined the staff of Montana State University library, Bozeman, as a reference librarian.

ANINDYAKumar Bose has been appointed assistant instructor in the graduate school to teach in the area of information and communication science at the University of Pittsburgh.

Patricia Bradley is the new Russian specialist in the catalog department at the University of Hawaii.

Mrs. Barbara Breakstone has joined the reference department, Freiberger Library, Case Western Reserve University.

E. BRidwell has been named head of the humanities division at Simon Fraser University.

George Brightbill has been appointed to the reference staff at Temple University.

Tyrone Broussard has been named map librarian at the Southern Illinois University library.

Mrs. Ellen Brow has been named assistant acquisitions librarian at the University of New Mexico.

D. BRucE is the new acting head of the sciences division at Simon Fraser University.

Susan Brynteson is now head of the order department of the University of Massachusetts, Amherst.

Mrs. George H. Bumgardner, Worcester, has been appointed curator of maps and prints for the American Antiquarian Society, a national research library of American history located in Worcester, Massachusetts.

Ruth-AnN Burton was appointed the assistant social science librarian at Kansas State University library on September 1, 1969.

Philip Calcagno was appointed cataloger for the Southern Illinois University library.

Alemander B. Carver has been appointed bibliographer at the Wesleyan University library.

Jane $S$. Carver is now assistant reference librarian at Wesleyan University.

Peter Chojenski has been appointed reference librarian and instructor in library science at the Purdue University Calumet campus, Hammond, Indiana.

Miss Soon Young Chung has been appointed assistant cataloger in the Teachers College library, Columbia University.

Mrtion Clasen has joined the staff of Texas A\&I University as assistant catalog librarian.

JACKSON CoHEN has been appointed head of the science and technology department of the Pratt Institute library.

Frederick G. Cook has assumed the position of cataloger at the Wesleyan University library.

Mary A. Davis has joined the staff of Temple University as science librarian.

Clifford Dawdy has joined the staff of Texas A\&I University as librarian of the Laredo branch.

Patricia Williams DeBardlebon is now circulation librarian, University of South Alabama, Mobile.

Anthony Debons has been appointed professor of information and communication science at the University of Pittsburgh.

Martin Dillon has joined the faculty of the school of library science, University of North Carolina at Chapel Hill, as assistant professor.

T. C. Dовв has been appointed assistant university librarian for information systems at Simon Fraser University.

Mrs. Shirley A. Doughty has been promoted to librarian in charge of collections development, York University libraries.

Mrs. ANN DraIN is now assistant chief of the reference department, Freiberger Library, Case Western Reserve University.

Marcia E. Duncan is the new government publications cataloger at the University of New Mexico.

RICHARD Duris is the new music librarian at Temple University library. 
The men: Information Dynamics Corporation's library systems
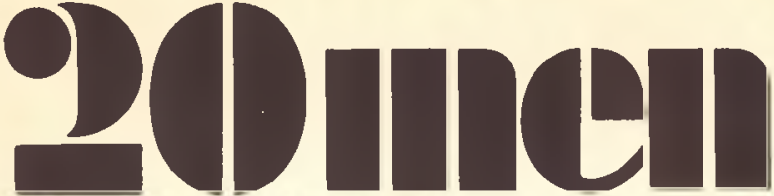
specialists.

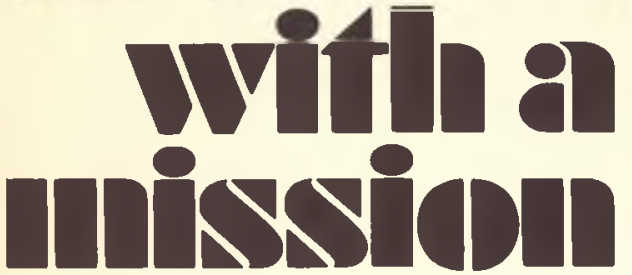

Located in major cities nationwide, these specialists are trained to (1) help you make a cost analysis to show you how the MCR System can save you money in your own day-to-day library operations and (2) provide competent and comprehensive service - from equipment installation to staff training and systematic follow-up.

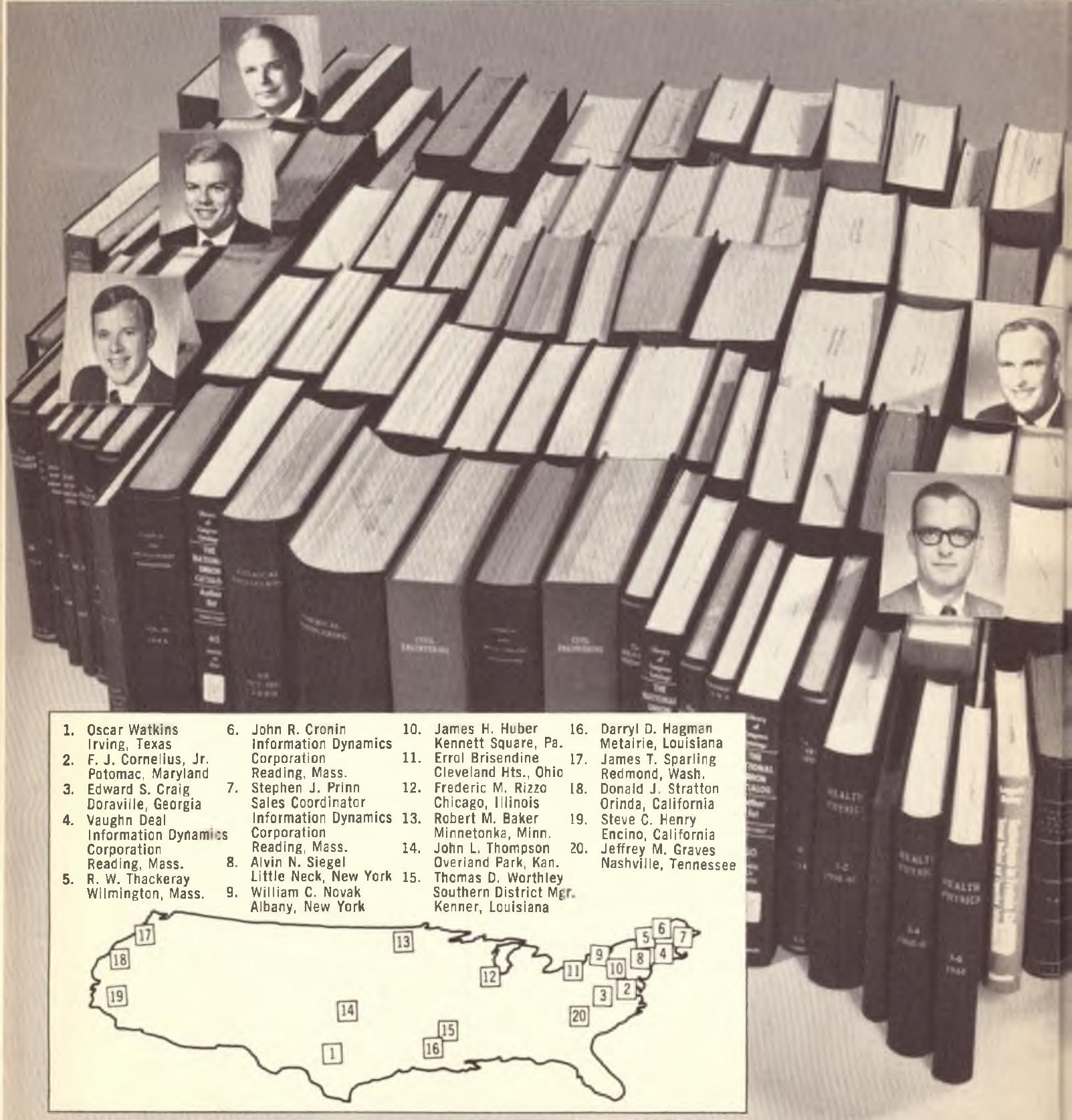


There's an IDC "Man With A Mission" not too far from you. He'll be glad to demonstrate the MCR System and show you the many ways this time-saving service can bring new speed and efficiency to your library operations - from reducing backlog to simplifying library expansion. Write us.

Information Dynamics Corporation, 88 Main Street, Reading, Mass. 01867

Millions of LC entries compressed into microfiche file speed search work for libraries equipped with the Micrographic Catalog Retrieval System. System includes Quick-Find Index, Reader-Printer, and variety of optional services to meet diverse cataloging and technical processing needs.

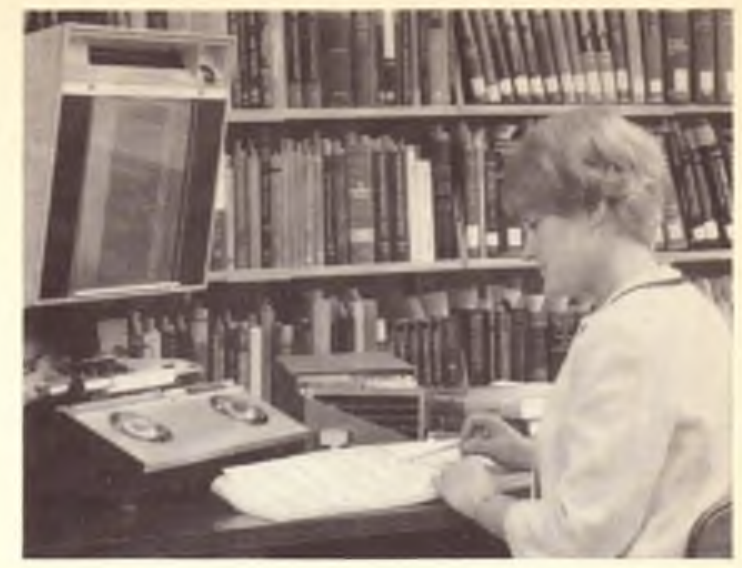

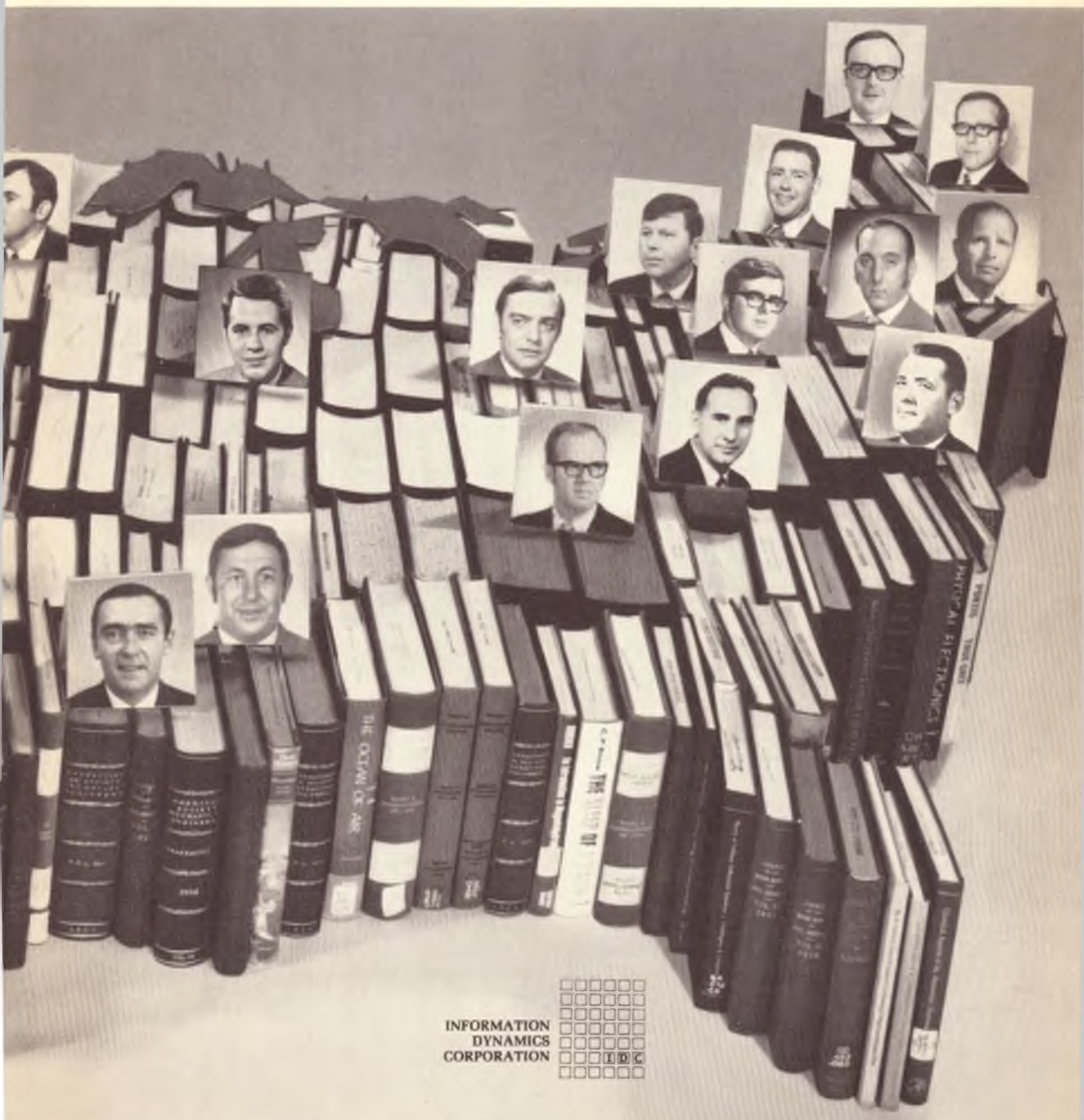


Virginia EDwards has been named serials catalog librarian at the University of Arizona.

Mrs. Elizabeth G. Eris has been appointed associate librarian and chief of the undergraduate libraries system.

Mns. VIRgINIA ElLISON was appointed reference librarian at Hofstra University library.

JAMES P. ELSE is now cataloger for the Honnold Library for the Claremont Colleges.

Peter L. Fenton has been appointed director of libraries at Elmira College, Elmira, New York.

JANNA Ferguson was appointed as a cataloger at Kansas State University library on October $1,1969$.

Mrs. Jayne K. Finney has been appointed head librarian, circulation department, at the Honnold Library for the Claremont Colleges.

Geratd Anton Fisher, Jr., has been appointed assistant professor jointly in the school of library science and department of computer information science at the University of North Carolina.

Frances Flick has been appointed senior acquisitions librarian at the University of Arizona.

Mrs. Barbara J. FlynN has joined the staff of the Honnold Library for the Claremont Colleges as periodicals librarian.

\section{COLLEGE LIBRARIANS!}

If you need a Dr. Seuss book, you might order it from a large trade jobber ( $B$ \& $T_{i} C$ \& $H, B-D$, etc.). If you need scholarly titles, you should contact Midwest Library Service!

For additional information, call us collect in St. Louis, Missouri-Area Code $314,739-3100$.

\section{MIDWEST LIBRARY SERVICE}

\author{
I |400 Dorsett Road \\ Maryland Heights, Missouri 63042
}

James E. Fountain has been appointed assistant special collections librarian at the Honnold Library for the Claremont Colleges.

Mrs. Susan H. Fowle has been appointed librarian II, Reference Department, York University libraries.

Carole Franklin has assumed the position of assistant librarian, music, in the arts library at the Pennsylvania State University library.

Mrs. Barbara Frissell is joining the staff as cataloger at the University of Hawaii.

Mrs. Natsuko Y. Furuya has been promoted to assistant director for technical services, York University libraries.

Hanold L. Geisse, Jn., has joined the staff at the Wesleyan University as cataloger.

ROBERT GERHARDT is the newly appointed science librarian at the Southern Illinois University library.

Alan M. Greenberg has joined the catalog division of the City College library, City University of New York.

JoN S. Greene is now bibliographer at the Honnold Library for the Claremont Colleges.

Marcanet Gregory was appointed as a cataloger at Kansas State University library on September 1, 1969.

Louis Hammack has assumed the position of cataloger at Temple University.

Judith Hathaway has been appointed cata$\log$ librarian at the University of Arizona.

Mrs. Margaret Herlinger was appointed as acting assistant head of the catalog division at Temple University.

JoAn HewITT is the new circulation librarian at the Southern Illinois University library.

Harruet Himmel is the new assistant education librarian at San Francisco State College library.

Mrs. Margaret Hinshaw is now assistant reference librarian at the Honnold Library for the Claremont Colleges.

Wendy J. Hiscott has been appointed circulation librarian, librarian I, Library of Osgoode Hall Law School of York University.

Allen J. Hogden has rejoined the staff of The New York Public Library as chief of the processing division in the research libraries.

Francis N. HogG, principal of the College of Librarianship, Wales, in Aberystwyth, Wales, has joined the faculty of the graduate school of library and information sciences of the University of Pittsburgh as visiting international professor for the academic year 1969-70.

JoAquin M. Holloway, JR., is now supervisor of instructional media, University of South Alabama library, Mobile.

Mrs. Anne Kelley Hoyt has been appointed to the position of assistant professor in the department of library education at Oklahoma State University.

Mns. Vlatka Ivanisevic is new interlihrary 
loan librarian, Freiberger Library, Case Western Reserve University.

Mrs. Julia D. Jacinto has assumed the position as cataloger for the Honnold Library for the Claremont Colleges.

PaUL JAMES, news editor of Hunter College of The City University of New York, has been appointed chief of public information at The New York Public Library.

Carolyn KaCENa has been appointed cata$\log$ librarian at the University of Arizona library.

Mrs. Ann R. Kahan has assumed the position of reference librarian at the Hofstra University library.

Mrs. Susan R. Kalienback has joined the staff of Temple University library as a cataloger.

Harold Kansas has accepted an appointment to be evening librarian in the Earl K. Long Library on the New Orleans campus, Louisiana State University.

Ellen Sue Kaplan has been appointed assistant reference librarian at the New York University Medical Center library in New York City.

Margaret Kelly has been named reference librarian at Temple University.

David Kraeuter has been appointed assistant librarian, public services, at Washington and Jefferson College library, Washington, Pennsylvania.

Mrs. Yadwiga Kuncaitis has joined the reference department, Freiberger Library, Case Western Reserve University.

LiNDA LEwis has assumed the position of assistant humanities librarian at the University of New Mexico.

WiLliam Lindstrom is the new head of the new gifts and exchange unit at the University of Hawaii.

Helen D. Lloyd, director of school media services for the Oklahoma City public schools, has been appointed an assistant professor in the school of library science at the University of Michigan.

Gertrude London is a newly appointed associate professor of library science at the University of North Carolina.

JAMES LU was appointed as the humanities librarian at Kansas State University library on September 1, 1969.

MARY Jo LYNCH is now senior reference librarian at the University of Massachusetts, Amherst.

C. W. MacDonald has been promoted to assistant university librarian for processing at Simon Fraser University.

Sylvia A. McDowell has assumed the position of head, serial department in technical services, at the Massachusetts Institute of Technology.
Many G. McLachlin has been appointed film librarian, York University libraries.

Martha Manheimer is now assistant professor of technical services and library resources for the University of Pittsburgh.

Samuel Markson is now head of circulation services of the University of Massachusetts, Amherst.

MaRy ANn Mayhew has been named data processing librarian on the University of Arizona staff.

Mrs. Bonnie Melton is now assistant to the university librarian at the University of Hawaii.

GARY MENGES is now coordinator of branch libraries at the University of Massachusetts, Amherst.

Margaret F. Meyn has accepted appointment as instructor in library administration, reference librarian, general reference division at the University of Oregon library.

George Miller, Jr., has been appointed circulation librarian at the University of New Mexico.

Carole Moldovanyi is the new bibliographer at Temple University library.

David Moore has assumed the position of acquisitions librarian at the University of $\mathrm{Ne}$ vada, Las Vegas.

ANN Joyce Morton has been appointed reference librarian and instructor at Monmouth College, Monmouth, Illinois.

RoBert MULLER, formerly associate director of the university library at the University of Michigan, was appointed as a professor of library science in the school of library science on September I, 1969.

IRENE MUNCHAK is now reference librarian at Marywood College, Scranton, Pennsylvania.

Eumer Newman has joined the reference department, Sears Library, Case Western Reserve University.

Gerald Palsson has been appointed senior reference librarian in the science division of the University of Arizona.

Richard Palumbo has been appointed rare book bibliographer at Temple University library.

Mrs. Grethe Parr received appointment as catalog librarian, instructor in library administration, the University of Oregon library, effective September 22, 1969.

Susanne Patterson is a reference librarian at the University of Nevada, Las Vegas.

Mrs. Madeline Peyton has joined the staff of Texas A\&I University as documents librarian.

Mrs. Susan Phillmps has joined the staff of Texas A\&I University as materials center $\mathrm{jj}_{-}$ brarian.

DAvid M. Pibel has been appointed to fill the new position of university archivist at Montana State University, Bozeman.

David PICCa joined the staff of Case Western 
Reserve University libraries as chief of the continuations department.

Merle Pincus has been promoted to acting head, catalog division, at the Temple University library.

Mrs. Janice Powell has assumed the position as head of general reference at the University of Hawaii.

STEPhen Powell has been appointed to the newly created position of special collections librarian at the University of Nevada, Las Vegas.

David F. Pownall is the new associate director of library services for Hofstra University.

Richand G. Racheten has been appointed catalog librarian for the Hofstra University library.

Mrs. E. Ann RaE has been appointed librarian I, cataloging department, the library of Osgoode Hall Law School of York University.

L. MiLes RaIsig has been appointed director of library services, Mary Livermore library, Pembroke State University, Pembroke, North Carolina.

Gordon W. Rawlins has joined the staff of Pennsylvania State University as senior assistant librarian and chief of systems development.

Mrs. Shirley A. Reuter has been appointed acquisitions librarian of the Nathaniel Hawthorne-Henry Wadsworth Longfellow library at Bowdoin College.

Mrs. AnN G. Ricker has been appointed librarian I, reference department, York University libraries.

Mrs. ANN M, Rrotro has been appointed supervising librarian of the reserve book room, Teachers College library, Columbia University.

LAwRENCE Rizzo has joined the staff of the University of Hawaii as humanities reference librarian.

Norma Rogers was appointed as assistant acquisitions librarian at the Kansas State University library on September 15, 1969.

Mrs. Constance Rose has been appointed assistant librarian in the reference department at the Pennsylvania State University library.

Richard Ross has assumed the position of phonorecord librarian at San Francisco State College library.

Mrs. Ellen Rudolph has been named first assistant in the acquisitions division at Temple University library.

Mrs. Rasma Rugelis has been promoted to head, cataloging department, librarian IV, York University libraries.

Donald J. Schippers has received the appointment of order librarian at the Honnold Library for the Claremont Colleges.

Thomas Schinmer has been appointed head of the circulation department of the Pratt Institute library.

EUnICE SHA has been appointed assistant cataloger in Teachers College library, Columbia University.

Marganet Shenwiv is now a cataloger at the Southern Illinois University library.

Vladmin Simosko joined the staff at the Forrestal campus of Princeton University library as assistant librarian.

Byung Kyu SoNg has been appointed assistant acquisitions librarian, instructor, on the staff of the Oklahoma State University library at Stillwater.

Hunter Stedman has joined the reference department, Freiberger Library, Case Western Reserve University.

Mrs. Helene Stern has accepted a position as librarian in a joint program with the Case Western Reserve University libraries and the Cleveland Institute of Music.

Mrs. Dorothy Stinson is now assistant chief of the circulation department, Freiberger Library, Case Western Reserve University.

Tову GaIL Stone was appointed assistant social science and humanities librarian at San Francisco State College library.

Mrs. Suzanne Striedieck has been named assistant librarian in the serials, microforms reclassification section of the catalog department at the Pennsylvania State University library.

Robert L. Stronc, Jr., is now head of reclassification at the Wesleyan University library.

Norman E. Tanis has assumed his new duties as college librarian at San Fernando Valley State College, Northridge, California.

Mrs. Rosemary Taylon is the new assistant cataloger of the Washington and Jefferson College library, Washington, Pennsylvania.

Pamela Thaxter has joined the staff at Temple University library as bibliographer.

Mrs. S. Thomas is the new head of the acquisition division at Simon Fraser University.

JoAnna Tond has joined the faculty of Stephens College as Readers' Services librarian.

Erma Jean Tolbert is now chief of the acquisitions department of Case Western Reserve University libraries.

Mrs. Cornelia Tucker has been appointed senior reference librarian at Temple University library.

Albert C. Vara is the newly appointed assistant head of the business section at Temple University library.

JAMES WALLING was appointed head of reprography at the University of Hawaii.

ELDON N. WANCura was appointed as assistant director of libraries for systems at Kansas State University on July 1, 1969.

Mrs. Frances Wang has been appointed curator of the Asian Studies Collection.

Mas. E. Sue WebeH is the catalog librarian for Hofstra University.

Irwin WeIntraub is the newly appointed 
assistant librarian, agricultural and biological sciences library at the Pennsylvania State University library.

Carrie Lynne West is now assistant director, Marquette University libraries, Marquette University, Milwaukee, Wisconsin.

Mrs. Marilyn Y. White has been appointed librarian II, cataloging department, York University libraries.

Mrs. Mrra White has been appointed head bibliographer at the Honnold Library for the Claremont Colleges.

James WrLliams has assumed the position of assistant instructor in the graduate school to teach in the area of information and communication science at the University of Pittsburgh.

Mrs. Judy R. Williams is now chemistry librarian at Columbia University in the city of New York.

Robert A. Winters is the new assistant university librarian for building and technical services at Princeton University library.

V'icki Dale Witheas has joined the staff of the Oklahoma State University library as assistant social sciences librarian.

Darnow Woon has joined the library department at New York City Community College, The City University of New York, as assistant acquisitions librarian.

SANDRA Young is now reference librarian at the University of Massachusetts, Amherst.

LORENzo A. ZeUGNER, JR., has been appointed assistant librarian and head of the library of the York campus of Pennsylvania State University.

BenEDICT $K$. ZoBnist, assistant dean of the faculty and chairman of the history department at Augustana College since 1965, has been named assistant director of the Harry $S$ Truman library at Independence, Missouri.

\section{RETIREMENTS}

ELEANOR G. STEINKE retired as librarian of the Vanderbilt University Medical Center library March 1, 1969. She was appointed head librarian in 1956, prior to which time she was assistant librarian.

volumes dated 1884, 1911, and 1914. Also: an unbroken series of 28 volumes covering the years 1936 to 1968 inclusive. Edwin A. Mason, P.O. Box 32, Lincoln, Mass. 01773.

Classified advertising orders and copy, and cancellations, should be addressed to the Advertising Department, 50 East Huron Street, Chicago 60611, and should reach that office before the tenth of the month preceding publication of issue desired. Copy received after that time may be held for the next issue.

Rate for classified advertising is $\$ 1.25$ per printed line. No additional charge is made for nonmember advertising.

GOVERNMENT PRINTING OFFICE publications at G.P.O. prices mailed within 72 hours. Order from Marv Broadbent, 4410 Josephine, Beltsville, Maryland 20705.

GOVERNMENT PUBLICATIONS mailed to you within 3 days. SuDocs price plus postage. Capital Documents Service, Box 4922, Washington 20008.

\section{OUT OF PRINT}

BOOK LANDERO, THE PERIPLUTIC BIBLIODICIST, 11501 Sherman Way, North Hollywood, $\mathrm{Ca} .91605$, specializing in OP tomes in Literature, Social Sciences, Humanities, especially as listed in BCL, Lamont, Essay Index, Granger, etc. Catalogs Issued. Wants searched through personal peregrinations and PANANABSES.

\section{FOR SALE}

U.S.D.A. YEARBOOK OF AGRICULTURE. For Sale-31 volumes in good condition for $\$ 100.00$ express collect. Included are: 3 historic
GEOLOGIC REFERENCE MATERIAL with emphasis on mineral economics consisting of tions relative to the Western United States, a 30 year collection, all out of print and over 1400 items in excellent condition. Price $\$ 14,500.00$ as a lot only in the original files. Will personally deliver up to 1000 miles of 919 Ouray Avenue, phone 303-242-1208, Grand Junction, Colorado.

\section{POSITIONS WANTED}

COLLEGE LIBRARIANSHIP or University Administrative position (Head, Assoc. or Asst. Directorship) sought by male, L.S. and Ph.D. degrees plus substantial university technical services, readers' services experience. Midwest or Pacific Coast preferred but will consider other. $\$ 15,000$ min. Box 765, CRL, 50 E. Huron St., Chicago 606II.

LIBRARIAN, man, 45, married. M.A. (Lib.), Ph.D. (French). Seeks challenging directorship in quality program college/university library. 17 yrs. exp., 13 as Hd. Libn. 9 yrs. college teaching, incl. Ind. Study Program Direction. Primary interests: collection building, library-curriculum-research integration. Building planning exp. Present salary $\$ 16,000$. Available July/Sept. 1970. Box 768, CRL, 50 E. Huron St., Chicago 60611.

FEMALE, M.S.L.S., 12 years varied experience. Background in sociology, political sciFederal, States and other Geologic Publica- 